\title{
Risk Management in Supply Chain Management: Case Study of a Brazilian Automotive Distribution Process
}

\author{
Diego A Wolfs \\ Universidade Metodista de Piracicaba \\ Brazil \\ Franco Takakura \\ Universidade Metodista de Piracicaba \\ Brazil \\ Maysa Rezende \\ UNIMEP - Universidade Metodista de Piracicaba \\ Brazil \\ Mauro Vivaldini \\ Universidade Metodista de Piracicaba \\ Brazil \\ Pedro Domingos Antoniolli \\ UNIMEP Universidade Metodista de Piracicaba \\ Brazil
}

Received: Sep. 23, 2015

Accepted: Oct. 19, $2015 \quad$ Published: October 25, 2015

doi:10.5296/jmr.v7i5.8354

URL: http://dx.doi.org/10.5296/jmr.v7i5.8354

\section{Abstract}

Globalisation requires from companies greater flexibility and adaptability of its internal 


\section{Macrothink}

Journal of Management Research

ISSN 1941-899X 2015, Vol. 7, No. 5

processes, to allow them be aligned to market requirements. This flexibility results in new forms of relationships between partners, supply chains. For these chains differentiate themselves from their competitors, they should add value to products and services that they deliver to the end customer, while being profitable from the standpoint of its processes and operations. In this sense, would be needed effective supply chain management, which is constituted by collaboration and cooperation among partners, strategic and processes integration, to result in a profitable operation, and products and services with added value to the customer. Additionally, because logistics is a key element for the integration and collaboration among SC members, and due the fact that, depending of the scope of these chains, there are potentially more risks happening, which may have negative impacts on the customer service level, and consequently, loss of effectiveness of their logistics processes. This study aims to analyze the risks in a product distribution process in the Brazilian automotive sector, considering the operations performed by a logistics operator of this automaker.

Keywords: Automotive Industry; Logistics Operator; Supply Chain; Supply Chain Management; Risks Management. 


\section{Introduction}

According to Hilletofth (2009), in the globalization early days, companies obtained economies of scale from the high volume production and distribution, with consequent cost savings. However, with increased competition, as a result of globalization itself, companies are forced to offer wider range of shorter life cycles products (CHRISTOPHER, 2011).

In this sense, the growing competition enabled the establishment of structures composed of several companies, called supply chains (SC), which began to add value to processes, increasing the service level and customer retention (LAMBERT and COOPER, 2000; RAINBIRD, 2004). On the other hand, they have changed this competition scenario, which is now no longer among individual companies, but among supply chains (LAMBERT and COOPER, 2000; CHRISTOPHER, 2011).

Thus, SC member's cooperation and collaboration were made possible, especially by the implementation of technologies, processes, tools and strategies, essential to increase SC performance and competitiveness, fact being treated in the literature by various authors (COOPER et al., 1997; ZHAO et al., 2008).

Some authors argue that cooperation between supplier and customer enables access to additional external resources. Rungtusanatham et al., (2003) and Slack and Lewis (2009) argue that such cooperation is source of competitive advantage. Towill et al. (2002) add that this advantage can decrease uncertainties reduction in supply, internal processes, controls, and demand. Lambert and Cooper (2000) adds inventory integration, and information sharing as responsible for increased customer service level.

This paper discusses the risks associated with the logistics process of distribution of a car manufacturer, located in Brazil, and subsequent handling of these risks to mitigate these risks impact and/or probability.

\section{Methodology}

Marconi and Lakatos (2010) argue that a problem must be defined in a clear and objective form. Thus, the gap being investigated in this article is described by the question: "What are the negative logistical risks associated with the distribution of an assembly plant process, and how they can have their impacts mitigated?"

Based on this context, basic assumptions include:

- Risk management approach is already used in several projects and processes, being considered essential to reach company targets;

- Performance of an automotive supply chain management can be positively influenced by the use of risk management approach on the distribution process.

Yet, according to Marconi and Lakatos (2010), a research can be classified under four dimensions: nature, approach, objectives and technical procedures.

These authors indicate that, with respect to its nature, a research can be considered basic, or 
applied. This article is classified as an applied research because it focuses theoretically in discussing the concepts and applications of risk management on automotive supply chains.

With regard to how to approach the problem, Marconi and Lakatos (2010) explain that research can be classified as quantitative or qualitative. This article is classified as qualitative research due to the method of interpreting the data, being its main focus on the process and its meaning.

Silva and Menezes (2000) argue that, in relation to the objectives, research can be classified as exploratory, descriptive or explanatory. This work is characterized as a descriptive survey because it involves the available literature review, and proposition of a systematic way to manage risks in the distribution process of an automotive enterprise, located in São Paulo, Brazil.

Talking about technical procedures, Silva and Menezes (2000) indicate that a research can be categorized as: bibliographic, documentary, experimental, survey, case study, research, ex-post-facto, action research or participatory research. This research is based on concepts and techniques described in the literature, and their application to manage risks into a distribution process of an automaker, being therefore classified as bibliographic. Additionally, the characteristic of the application of these concepts in a particular case falls into the procedures of case study.

The choice of case study is contingent and convergent with the nature of the problem, and the current state of knowledge. The following considerations justify the method choice:

- This study focus is the risk management usage in distribution process, in a automotive supply chain structure. Regarding these concepts and application, the available literature is scarce;

- The knowledge level lies on development early research stages. Thus, case study proves to be the most appropriate approach for the proposed research. As suggested by McCutcheon and Meredith (1993), Yin (2004) and Eisenhardt (1989), this approach is typical in the early stages of the development of theory, where events or phenomena, have little or no cataloged knowledge.

\section{Supply Chain and Supply Chain Management}

Lambert and Cooper (2000) define supply chain as "a network of companies with multiple business and relationships, in which each link provides facilities so that the product get value along the chain".

Mahdavi et al. (2009) consider supply chain described as inventory systems, formed by various levels and locations. Christopher (2011) complement, explaining that the SC can add value through two ways: low cost (process efficiency); or differentiation (innovation). The author, however, believes that both alternatives require SCM processes revision and optimization, since activities that do not add value, contribute to costs aggregation, derived specially for the involved resources usage. 
Quinn (1997) states that supply chains are composed of all activities related to the products flow, on which there is value addition.

In this sense, "value" may have complementary definitions, as presented by Woodruff (1997) and Christopher (2011), and essentially consist of:

- Value for the customer is based on a product or service use and adherence;

- Value is perceived from the customer perspective, not from the supplier;

- Value typically involves a trade-off between what the customer gets, for what he pays.

For Mentzer et al. (2001), SC can be defined as a set of three or more entities, which may be organizations or individuals involved directly in a flow upstream and downstream of products, services, and financial information, from a source to a client.

Lambert et al. (1998) classify SC participants as primary, and support members. So, primary are companies that perform processes that add value to the final product and / or service, while the support are those enterprises that provide elements (resources, knowledge, etc.) to support the SC primary members, and do not participate directly on addition value.

On the other hand, supply chain management (SCM) can be conceptualized as the integration of the chain downstream and upstream organizations processes, producing value for the end customer (CHRISTOPHER and RYALS, 1999; LAMBERT and COOPER, 2000). Within this approach, Lambert et al. (1998) conceptualize process as a set of operations or tasks that produce a specific output.

The Global Supply Chain Forum (GSCF) defines SCM as the integration of key business processes, considering links from the end customer to the original supplier, which provides products, services and value-added information to customers and other stakeholders (CROXTON et al., 2008; LAMBERT and COOPER, 2000; LAMBERT et al., 1998).

The Council of Supply Chain Management Professionals (2015) considers that the supply chain management involves both the planning and the management of activities related to the products acquisition and supply, besides those related to processing and logistics management, including coordination and collaboration among the SC participants.

Mentzer et al. (2001) follow the same line of other authors, featuring SCM as the strategic and operational coordination of business functions, both internal and inter-organizational, with the goal of optimizing the overall results of this $\mathrm{SC}$, in the end.

Yet, according to Mentzer et al. (2001), SCM can be defined as "the systematic coordination, strategic and tactical traditional business functions (marketing, sales, research development, planning, production, purchasing, logistics, information technology, finance and customer service) within the company through the business functions and within the through business supply chain, in order to improve long-term performance of individual companies and the chain as a whole ". Complementing this scenario, Christopher (2011, p.14) points out that the concept of SCM, even being relatively new, has as one of its main concerns, logistical flows and ways to optimize them. 
Mentzer et al. (2001) point out that SC participating companies must be willing to share values such as trust, commitment, interdependence, organizational compatibility, vision, key processes, leadership, and support from senior management (Figure 1). Companies should also have an orientation for the supply chain effectiveness, which means shared strategic and systemic vision. As a result of supply chain management, alliances between companies with customers, service goals, and similar focus are aligned, which meet the pursued business requirements, in order to share information, risks and results, integration of its key processes and cross-functional coordination, establishing long-term relationships. That done, consequences, or expected results, are: reduced costs, improved customer satisfaction, and better competitive advantage.

Jabbour (2009) complements, indicating that SC adoption approach has been evidenced by market practices, like; a) restructuring and reduction of suppliers number; b) information on solutions sharing; c) application of EDI (Electronic Data Interchange), JIT (Just in Time), ECR (Efficient Consumer Response), QR (Quick Response) and CR (Continuous Replenishment) practices; d) process integration among SC members in the early stages of product development (ESI - Early Supplier Involvement), into SC operations (IPR - In Plant Representatives), better inventory management process (VMI - Vendor Managed Inventories); e) design of products with great ease and flexibility during handling and other logistics processes, as well as manufacturing postponement (lag of goods decoupling point, nearest to the end customer), as stated by Tan et al. (2002), Pires (2004), Wong et al. (2005), Wanke (2010), and Christopher (2011).

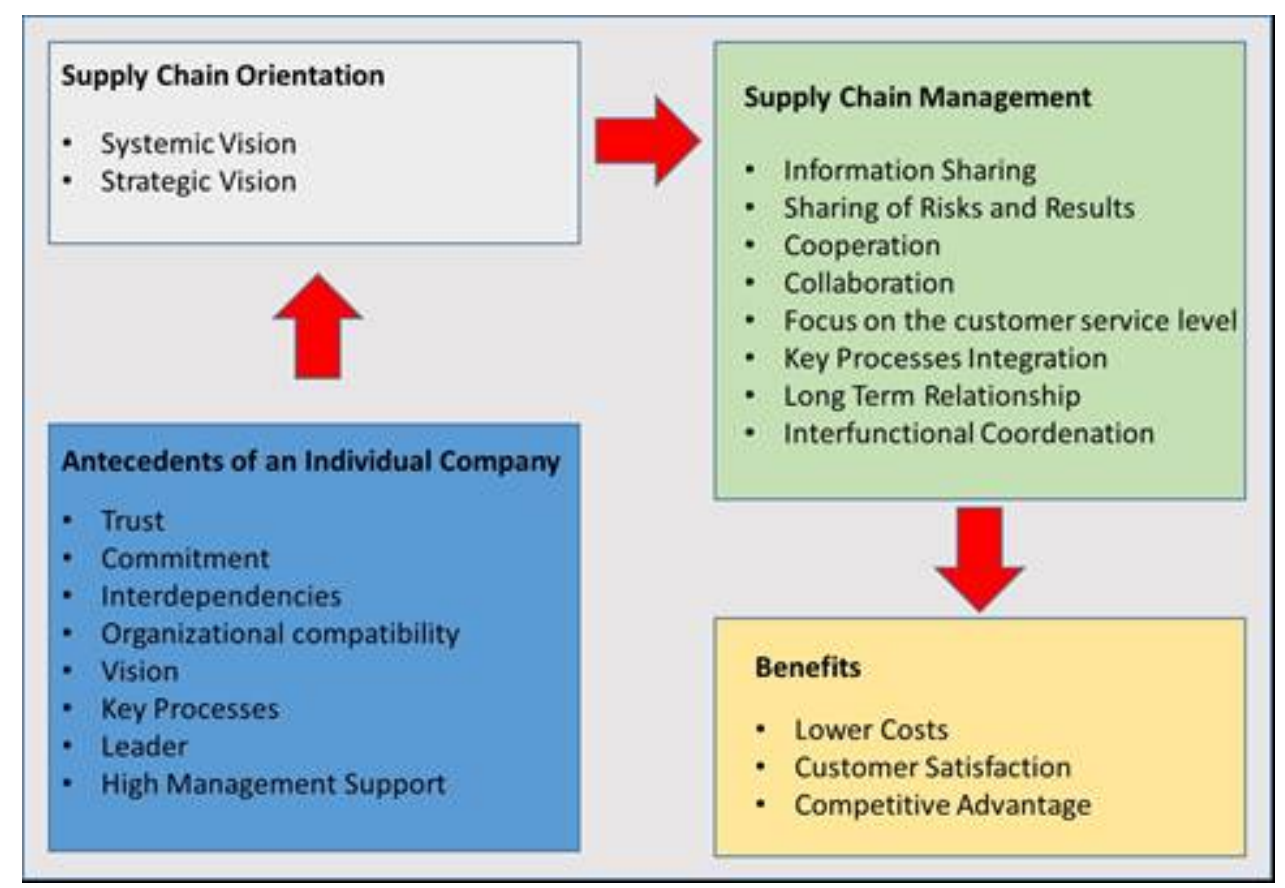

Figure 1. SC Antecedents and Consequences. Source: Adapted from Mentzer et al. (2001).

Cooper and Pagh (1998) cite three foundation elements of SCM: the structure (vertical, horizontal, and position of suppliers in the SC), processes (set of activities to add value in the chain), and components (management activities of integrating processes along the chain). 
In order to help managers decide how to proceed in the direction of supply chain management, Anderson et al. (1997) compiled initiatives related to this issue, undertaken by successful entrepreneurs of that time, and organized in seven fundamental principles to support supply chain management: (1) segmenting customers, based on different groups of service needs, and adapt the SC to serve these segments, in a profitably way; (2) customize the logistics network to service requirements of customer segments; (3) listen to market signals and align demand planning accordingly, across the SC, providing forecasts and resources allocation consistently, minimizing the inventory volumes and stocks costs; (4) differentiate products and streamline the distribution by SC, improving the ability to respond to market signals, compressing lead times, accelerating the conversion of raw materials into products tailored to customer needs; (5) manage the sources of supply strategically to reduce materials and services total cost of ownership (TCO); (6) develop a technology strategy across the SC that supports multiple levels of decision-making, and provide a clear view of the goods, services and information flows; (7) adopt performance measures covering the entire chain to measure the collective success in achieving the ultimate client effectively and efficiently, adopting measures / indicators that can be applied to all links of the supply chain, including services and financial.

Wanke (2010) states that SC integration is undermined by the complexity of aligning partners strategic priorities, besides the adherence degree of these priorities with chain goals, as: a) differences in fixed and variable costs structure; b) different operations response times of partners enterprises; c) contribution margin for the products being marketed; d) lack of excesso inventories; e) high rate of obsolescence, caused by the wide products variety; lack of information, or incomplete one.

Christopher and Peck (2004) support the approach of Wanke (2010), stating that markets have become more fragmented and volatile, providing management challenges and adoption of new practices in SCM.

Even SCM has turned into a powerful business configuration, able to leverage their participants companies and competitiveness, is not free of risks, and face several threats to operate in this direction.

\section{Supply Chain Risks}

Supply chain management is a kind of productive configuration that is in evidence in the contemporary market, as an important means to achieve and enhance competitive advantage through product flows, services and information, delivering reduced costs, faster and more reliable order management, in order to satisfy end customer needs and expectations. However, supply chains are inherently prone to risk events (AGUIAR, 2010).

Thus, relating the pursuit of effectiveness of the chain, companies should seek ways to diminish the events that can be harmful to these chains, managing the risks. In this sense, risk management in the SCM (SCRM - Supply Chain Risk Management) is related to the identification and control of risks, and may provide efficiency in the processes into the chain operation, an orderly approach between the links of the chain, preventing or mitigating the 
vulnerabilities of the chain as a whole (CRANFIELD, 2006; JUTTNER, CHRISTOPHER; PECK, 2004; CHRISTOPHER, 2011).

Based on Ghade, Dani and Kalawsky (2012), risk management in the current market is becoming increasingly challenging, mainly because of uncertainties in supply and demand, besides global sourcing and reduced life cycles of products. Risk, in this context, may be understood as the potential unwanted negative result, arising from an event or activity. Currently, the business environment is controlled by various indicators and tools, such as: financial return, just-in-time, mergers, outsourcing, new technologies, sales through virtual channels, forcing organizations to adopt new ways of doing business (STEFANOVIC et al., 2009).

However, even globalization makes companies more competitive as they are structured in supply chains; this fact makes them more vulnerable, related to their external operations. Vulnerability, in this case, is defined as an exposure to the severe disruption, caused by risks within the SC, and external risks to these chains (CHRISTOPHER and LEE, 2004).

$\mathrm{Wu}$ and Olson (2009), mention that specific industry supply chain may have different degrees of exposure to risk. This chain structure can be the source of various risks within their participant organizations. The industrial sector may have reduced risk due to decision-making regarding the supplier's selection. In risk management, partnership must be founded on financial solvency, product quality features, compatibility and capabilities of the provider's information systems. Another chain element exposed to risk is the business, which means internal organizational processes and existence of control mechanisms in place, improvement in equipment, training people, and also improvements in the decision processes, supported by efficient information systems, which are fundamental to mitigate risks.

Risk management, in this sense, has the higher purpose of the identification of risks and its focus, considering enterprise sustentability and corporate competitiveness (WU and OLSON, 2009).

Thus, systematic risks are identified in several SC links, being necessary to prioritize the greatest impacts and probabilities existing on these risks, which can be considered critical success factors of organizational goals.

\subsection{Supply Chain Risks Components and Characteristics}

Risk is the uncertainty that affects the well-being of an individual or a business, and is often associated with adversity and loss (GIHA, 2013). Peck (2005) points out that the basic nature of the risk is related to a product or event. Uncertainty is a situation where a person or organization is not sure what will happen, being likely to occur risk. However, uncertainty does not necessarily lead to a hazardous situation. In other words, the risk is the uncertainty that "matters / events" can cause a financial loss, potential damage to human health, the "after-effects" that affect resources, and other situations that affect a person's (or) wellness companies.

Risks in SC can be defined as "an exposure to an event that causes disruption, affecting the 
efficient management of the SC network". Risk management has become an integral part of a holistic SCM project (CHRISTOPHER and LEE, 2004). Thus, it is understood that there is a classification of the various risks in the SC. The risk itself can be termed as interruption, vulnerability, uncertainty, disaster, danger and risk. The academic literature within the domain of the SC has sought to differentiate between the various forms of risk, focusing on the availability of information and the intensity of such events. Thus, this can vary from completely unknown until fully known and immediate danger.

Ghade, Danie and Kalawsky (2012) define risk as an uncertainty for the SC, where the decision maker lacks information about the SC network and / or the environment and, therefore, is unable to predict the impact of the event on the chain behavior, although the risk and uncertainty are used interchangeably in the supply chain. However, it can be understood how the uncertainty immeasurable, since the complete certainty but a possibility of events.

Moreover, the risk is measured as a result of uncertainty, but with some possible loss, or other undesirable results occur (HUBBARD, 2009). According to Williams et al. (2008), safety within the $\mathrm{SC}$ is a subcomponent of the overall risk, and should be element to be considering, in management strategy within the chain and organization.

Risks can be made up of several elements, with different connotations, such as physics, structural, economic, social and environmental, divided into several members, and successive detailing scales, which makes necessary that risks be monitored and controlled (GUIMARÃES, 2006).

Tummala and Schoenherr (2011) define SC risk as "an event that negatively affect supply chain operations, and therefore their desired measures performance". Like risks faced by individual companies, the risks of SC can also be classified in different ways, and from different perspectives. Tang (2006) suggests that there are two types of risk in a supply chain. First, those called operational risks, arising from uncertainties in demand, supply and cost, which, by their nature, are always present. Secondly, the risk of breakage, arising from natural disasters, such as weather disturbances, or economic crisis.

An additional classification is mentioned by Giha (2011), indicating that within a company, there are "processes" and "control" risks. The first are those risks associated with disruptions in value-creation processes, and management activity within the company, while the control risks are those connected with a division, or misapplication of the systems and standards, used to monitor processes. External to the company, but within the chain, are the network risks, which can be divided into "demand" and "supply" risks. Demand risks are those related to the product flow, information or revenue between a business and its customers. Similarly, the risk of supply is related to inefficiencies in the supply of materials and services, information and monetary flows, between a company and its supplier.

The fifth category SC's risk refers to interruptions that are outside the organizational network that make up the supply chain, called "environment". Those are the risks that refer to events that can directly impact the company, or its upstream supply system and downstream. They can be: social, political, economic, technological, or environmental, which are events that 
affect the environment in which SC operates.

With a more synthesized concept, Cucchiella and Gastaldi (2006) reported that the SC is divided into two risk categories: 1) internal risks, involving issues such as variations in capacity, regulations, reporting delays, and organizational factors, material resources, intellectual capital, finance and others; 2) external risks, related to external market prices, corporate actions risk, management of competitors, production yield and cost, quality suppliers, economics, law and politics.

Additionally, Kleindorfer and Saad (2005) categorize risks as results of coordination of complex supply and demand systems (internal), and interruptions (external). The supply chain management, therefore, have to worry about the risks from all types, both from the macro environment, as the microenvironment. In any business, opportunities arise from the organizational ability to manage risks. Most of the risks of natural phenomena are handled through diversification and redundancy, or through insurance, both of which have inherent costs. The analysis must, therefore, be performed accurately in relation to costs, to reduce the risk of financial compensation. Additionally, operating transactions must be monitored and controled, since its implementation. The costs and benefits are critical to decision-making in risk management implementation.

A systemic process is suitable to monitor risks. In this sense, Cucchiella and Gastaldi (2006) describe the steps for the SC risk management implementation: (1) analysis: examine the supply chain structure, appropriate performance measures, and responsibilities; (2) identify sources of uncertainty: to focus on the most important; (3) examine the risks: selecting the risks of controllable sources of uncertainty; (4) manage risks: develop strategies; (5) individualized, considering the option and evaluate the most appropriate strategy for each risk; (6) implementation: it can be combined with a generic risk management process; (7) risk response process: perceiving threats, identifying faults, and thereby recognizing the adverse consequences; planning an appropriate response, such as the preparation of a mitigation plan and / or contingency; (8) risk assessment (business and managerial risks): which considers risks analysis and quantification, estimating probabilities; estimate importance of these risks, risk acceptability, cost / benefit analysis and; (9) the selection of appropriate risk management strategy; (10) execution: partnerships related to security; and organizational adaptation; (11) the accompanying risk / mitigation: communication and security of information technology; the initial requirement is to specify the nature of the hazards that lead to underlying risks; risk needs to be quantified through disciplined risk assessment, to include establishing links that cause risks; to manage risk effectively, the approach should meet the environmental decision needs; appropriate policies and management actions must be integrated with ongoing risk assessment and coordination.

\section{Case Study: Logistics Service Provider in the Automotive Industry}

\subsection{The Company}

For this research case study, was considered the existing distribution scenario in a company of the automotive sector (called Company A), that currently has an annual production 
capacity of 150,000 vehicles. The company is located in Brazil, specifically in the state of São Paulo, and has just over 2,700 employees.

Currently the company is dedicated to attend the country domestic demand, and operates in the compact vehicles segment. The company has developed a partner to carry out the distribution of vehicles produced in the country, which is responsible for all company logistics processes. Local carriers, under the supervision of the logistics partner, can also perform transport.

The vehicles distribution takes place for all Brazilian states (about 25 states), being directed to dealers or strategic distribution centers, and located in every state.

\subsection{The Distribution Process}

The distribution process begins by the truck load order, that is directed to the company's load center of the logistics company, responsible for the transportation. Additionally, this shipment order is sent electronically to the dealership, or to the target distribution center. A truck entrance permission is also directed to the truck entrance lobby, which conferred the names of those responsible for transport, and authorizes the shipment.

This loading order has some standard items as: release of the carrier; the name of the driver responsible for transporting; vehicles must embark with its chassis and his ordination as loaded onto the truck; and the name of the conference responsable operator.

The trucks are able to transport from 8 to 11 cars, depending on the vehicle configuration. Drivers must present their validated drivers licences document, besides the truck load order, as their arrival in the company to proceed the load.

Being released, the driver must position the truck beside the loading center, with the support of the responsible of the assemble car company. Trucks should be parked in the loading site where the cars are positioned to cargo shipment. Cars may be ordered for loading or not, also depending on the milk run configuration.

Before loading, an operator must execute a loading checklist. This checklist considers internal and external elements of the truck. If any problem arises, the department responsible for parking the cars in the place should be communicated, and another car is positioned, which is subject to new checklist.

After the execution and approval of the checklist, the load is released, and then the truck is ready for shipment. Some security procedures are adopted, such as the use of Personal Protection Equipment (PPE), conference and preparation of the boarding ramp, check ramp pin, check the fit of the ramp trailer, etc.

For shipment, a person entitled loader should perform the cargo loading. Initially the cars are positioned on top deck of the truck, and then the loading is carried out the bottom of decks's truck. Before shipment begins, a person should check and prepare all the ropes and straps used to ensure that the car will not move when the truck is moving. Only with the permission of the loader operator is that the process of rising vehicle starts. 
Only one vehicle at a time should move into the ramp. The car is deployed and the hand brake set. The car is then bound by the corde. After release, other vehicle may be picked up and the process is repeated until the truck is totally charged.

Being all vehicles loaded, the ramp is positioned again so that the truck is closed and the ramp is then locked, where another verification process ensures that all nameplates and safety pins are positioned.

Vehicle keys are delivered to the driver or, in some cases, sent directly via pouch to the dealership, along with DANFE (Brazilian Electronic Invoice Document). The company also conducts the delivery of CT-E (Electronic Bill of Lading).

After final verification performed by the driver, and loader, a new checklist is performed and, if everything is correct, the truck is released. The driver is directed to the exit gate, and presents the DANFE, where it is then released for transport and travel.

Drivers, whenever reaching destination city, must notify the carrier. They must also communicate to each toll their position. The trucks are tracked and monitored by the company responsible for the logistics, via GPS (Global Positioning System). The estimated time of cargo arrival is informed to the distribution center, or destination dealer.

Upon arriving at the dealership, the driver must deliver the DANFE and CT-E to the receiving department, as well as vehicles keys (if not sent direclty). At this moment, some conference proceedings are run, composed by a checklist prepared by the dealer. Cars are untied and go down from the truck, starting from the bottom of the truck's deck and then from above. They are properly positioned in the courtyard of the dealer, and the driver signoff the delivery confirmation. The same landing process occurs in the case of distribution centers.

During long trips, drivers should position the truck in appropriate places, such as gas stations patios, that have resting place, whenever they need to stay during night. Drivers are not allowed to change any aspect of the charge, nor make some deviation from their planned route.

In the shipment case, may be directed for more than one dealer, on the same trip, and the vehicle should be positioned in such a way that they can be removed from the first and second Dealers, so on, a process called milk run.

\subsection{Process Risks Identification and Analysis}

Risk identification went through a process of analogy, based on the company's own documents, and through brainstorming with the main actors involved in the loading and logistics control, until the arrival at their final destination. Was applied an open assessment, to seven drivers, two loaders operators, and also two dealer's receiving supervisors, based in a single question: "Based on the cars loading, transportation and unloading processes you execute, what are main risks you can identify, and from which kind?"

The risks were identified and organized into categories, based on the sequential processes. 


\section{$\triangle 1$ Macrothink}

From the definition of the groups, an risk breakdown structure was defined (RBS), as shown in Figure 2.

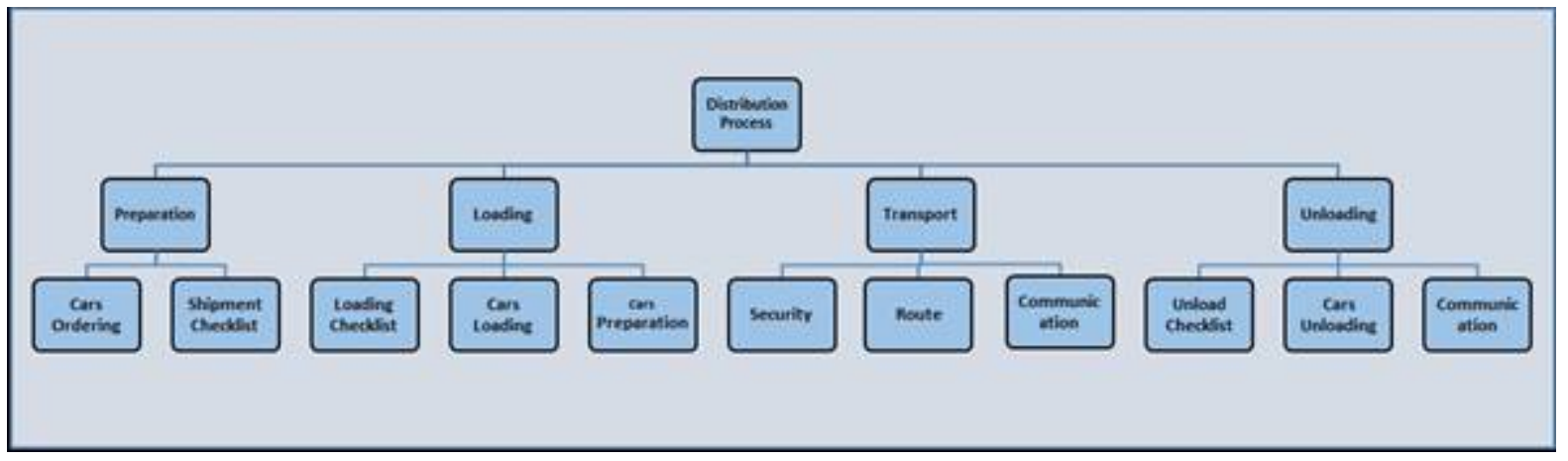

Figure 2. The Process Risk Breakdown Structure of the Distribution Process.

Based on the identified risks, grouped into categories, qualitative analysis of each risk is done, which estimates their severity on risk probability and impact.

\subsection{Risk Analysis and Response}

Table I. Main risks identified in the evaluated process.

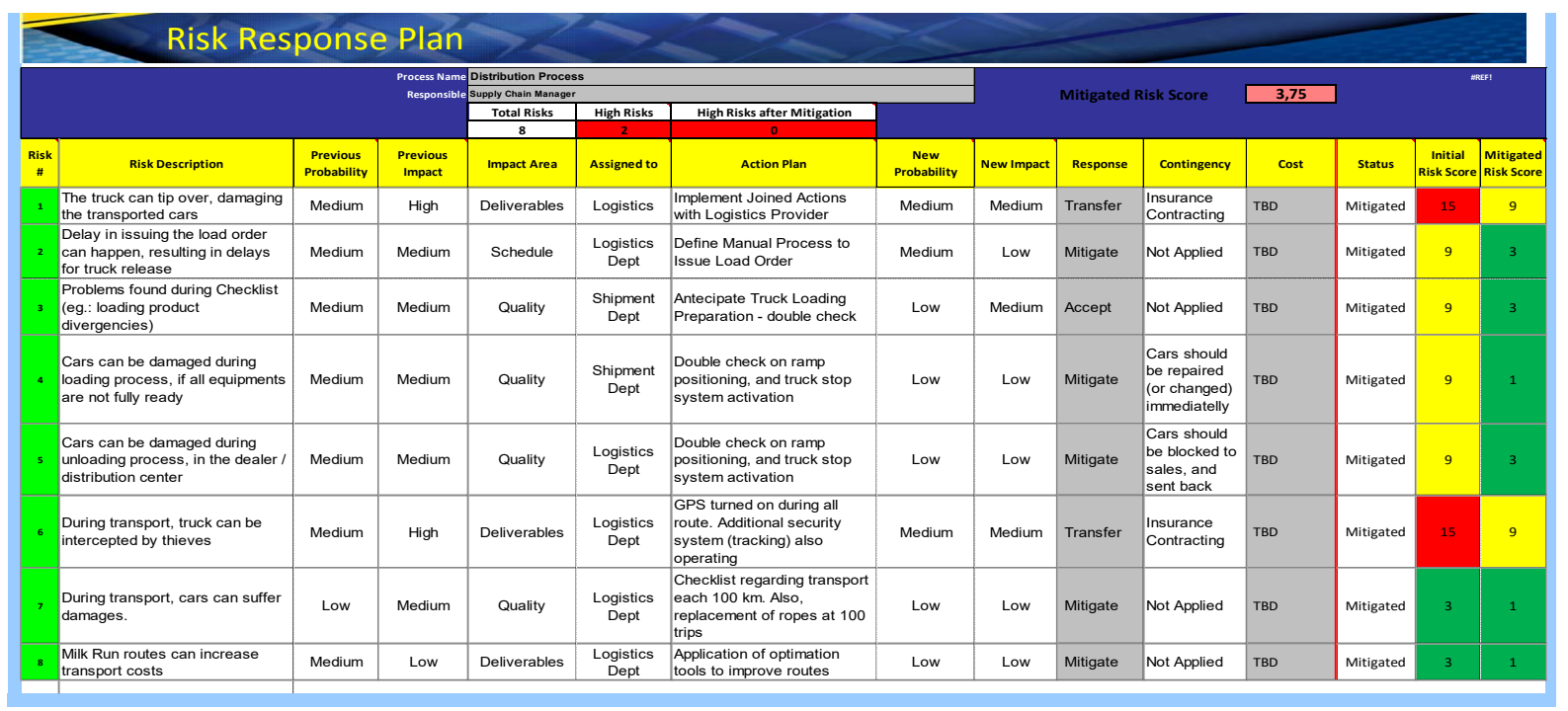

Based on the identified risks, a qualitative analysis was performed, measuring each risk probability and impact, and the severity impact for the distribution process. To qualify probability and impact, was defined an index, which content is based on the Likert scale, being 1 the lowest, 2 the medium, and 3 the highest.

The results show that there are several risks associated with transport, as the process of vehicles loading and unloading, besides documentation preparation for the shipment. Accordingly, action plan was drawn for each of the risks hazards, and some include mitigation (with actions both to reduce the risk probability, as the impact, as both), others involve the risk response to the transfer of risk (as insurance contracting). 
According to the results, two risks are critical to this process, and both are related to transportation, indicating this should receive more caution whenever handled, in terms of risks. They are:

- Risk 1: Truck can tip over: this risk requires joined actions from the Company A and its LSP (Logistics Service Provider) to be mitigated. Besides, some contractual responsibilities must be stated in the service contract. This fact can make the risk impact shared between Company A and its LSP;

- Risk 5: Truck can be intercepted by thieves: Due the Brazilian territory extension, not all roads have the enough police monitoring, which make the risk more probable to happen. Therefore, technological monitoring devices should be present in the truck, in order to track the trip conditions and steps. In addition, a previous registration and tracking of the truck driver can mitigate undesirable events. Therefore, among the identified risks, this is the most critical, and requires additional support, which, in Brazilian case, consider armed escort, in some dangerous routes.

Thus, for the process analyzed, the following steps were followed: (1) risk identification; (2) risk categorization; (3) qualitative risk analysis; (4) development of risk responses, with a corresponding action plan.

However, risks can change their behavior, which forces continuous monitoring, and tracking.

\section{Conclusion.}

In this paper, was adopted the concept of SC proposed by Lambert, Cooper and Pagh (1998), whose focus is set from a company, and comprising all the organizations that have direct and indirect relationship with this organization. In addition, the main elements relating to risk management in SC were identified, based Cucchiella and Gastaldi (2006), Giha (2011), which are based on processes performed in the SC, to identify the risks, categorizes them, and establish a plan action to mitigate the potential occurrence and impacts of these risks on SC operations.

From these elements, was attempted to identify, in a logistics operator distribution process of an automotive chain, the risks in this process, being done its qualitative analysis, and mitigation plan for such risks.

One of this study assumptions was that in a supply chain, especially into the automotive sector, control and monitoring of risks in logistics processes contributes to this chain better performance, resulting in greater speed and reliability, hence better level service, and lower costs, obtained through more reliable and safe distribution processes. It was found that the identification and treatment of the inherent risks in this distribution process collaborate decisively to achieving them.

Another assumption was that, if there is integration of the involved partners processes, better performance is present. It was found that, through a process of governance and integrated risk management, this goal can be achieved, with lower costs, generating optimization and increased delivery reliability, better product quality and service, and lower logistics costs. 
Thus, this study purpose was, based on the existing literature and field research, identify which risks should be monitored and treated in car distribution process, performed by a logistics operator of a carmaker, whose factory is in São Paulo.

This research, however, should be extended to other sector supply chains, as well as for other types of chains, whose performance objectives, and product characteristics are different, to verify that the identified risks are relevant, which requires new studies, since this is one of the limitations of this research, the fact that this research was done in a single case study.

\section{References}

Aguiar, E. C. (2010). Contribuição ao estudo do fator risco no desempenho de organizações e cadeias de suprimentos. Tese (Doutorado em Administração)- Faculdade de Economia, Administração e Contabilidade, Universidade de São Paulo.

Anderson, D. L., Britt, F. F., \& Favre, D. J. (1997). The Seven Principles of Supply Chain Management. Ten Classics from Supply Chain Management Review, www.scrm.com.

Christopher, M. C. (2011). Logistics and Supply Chain Management, 4th ed., Prentice Hall, NY.

Christopher, M., \& Lee, H. (2004). Mitigating supply chain risk through improved confidence. International Journal of Physical Distribution and Logistics Management, 34(5), 388-96. http://dx.doi.org/10.1108/09600030410545436

Christopher, M. C., \& Peck, H. (2004). Marketing Logistics, Elsevier, New York, NY.

Christopher, M., \& Ryals, L. (1999). Supply chain strategy: it's impact on shareholders value. International Journal of Logistics Management, 10(1), 1-10. http://dx.doi.org/10.1108/09574099910805897

Cooper, M. C., Lambert, D. M., \& Pagh, J. D. (1997). Supply chain management: more than a new name for logistics. International Journal of Logistics Management, 8(1), 1-14. http://dx.doi.org/10.1108/09574099710805556

Council of Supply Chain Management Professional - CSCMP (2015). Supply chain management Definitions. Available in: $<$ http://cscmp.org/aboutcscmp/definitions.asp?XX=1> Access in: 20 jul. 2015.

Cranfield School of Management (2002). Supply chain vulnerability. Final report on behalf of DTRL.

Cucchiella, F., \& Gastaldi, M. (2002). Risk management in supply chain: a real option approach. Journal of Manufacturing Technology Management, 17(6), 700-720. http://dx.doi.org/10.1108/17410380610678756

Croxton, K. L., Lambert, D. M., Garcia-Dastugue, S. J., \& Rogers, D. S. (2008). The Demand Management Process. In: LAMBERT, D.M. Supply Chain Management: Processes, Partnerships, Performance. Florida: Supply Chain Management Institute, 2008, 87-104. 
Eisenhart, K. M. (1989). Building theories from case research. Academy of Management Review, 14(4), 532-550.

Ghadge A, Dani S., \& Kalawsky R. (2012). Supply chain risk management: present and future scope, UK, The International Journal of Logistics Management, 23(3), 313-339 r Emerald Group Publishing Limited 0957-4093.

Giha, P. L. C. R. (2013). Risk and resilience in agri-food supply chains: the case of the ASDA PorkLink supply chain in Scotland. Supply Chain Management: An International Journal 18 (2), 219-231 q Emerald Group Publishing Limited [ISSN 1359-8546].

Guimarães, C. M., \& Carvalho, J. C. (2012). Terceirização em cuidados continuados: uma abordagem de gestão de risco. Ciência \& Saúde Coletiva, 17(5), 1179-1190. http://dx.doi.org/10.1590/S1413-81232012000500012

Hilletofth, P. (2009). How to develop a differentiated supply chain strategy. Industrial Management \& Data Systems, 109(1), 16-33. http://dx.doi.org/10.1108/02635570910926573

Hubbard, D. (2009). The Failure of Risk Management: Why It's Broken and How to Fix It, John Wiley and Sons, Hoboken, NJ, p. 211.

Jabbour, A. B. L. S. (2009). Prioridades Competitivas da Produção e Práticas de Gestão da Cadeia de Suprimentos: uma survey no setor eletroeletronico brasileiro. Tese (Doutorado em Engenharia de Produção) - Programa de Pós-Graduação em Engenharia de Produção, Universidade Federal de São Carlos.

Juttner, U., Christopher, M., \& Peck, H. (2003). Supply chain risk management outlining an agenda for future research. International Journal of Logistics Management, 6(4), 197-210. http://dx.doi.org/10.1080/13675560310001627016

Kleindorfer, P. R., \& Saad, G. H. (2005). Managing disruption risks in supply chains. Production and Operations Management, 14(1), 53-68. http://dx.doi.org/10.1111/j.1937-5956.2005.tb00009.x

Lambert, D. M., \& Cooper, M. C. (2000). Issues in supply chain management. Industrial Marketing Management, 29(1), 65-83. http://dx.doi.org/10.1016/S0019-8501(99)00113-3

Lambert, D. M., Cooper, M. C., \& Pagh, J. D. (1998). Supply Chain Management: Implementation Issues and Research Opportunities. International Journal of Logistics Management, 9(2), 1-19. http://dx.doi.org/10.1108/09574099810805807

Mahdavi, I., Mohebbi, S., Zandakbari, M., Cho, N., \& Mahdavi-Amiri, N. (2009). Agent-based web services for the design of a dynamic coordination mechanism in supply networks. Journal of Intelligent Manufacturing, 20(6), 727-749. http://dx.doi.org/10.1007/s10845-008-0173-6

Marconi, M. A., \& Lakatos, E. M. (2010). Fundamentos de Metodologia Científica. São Paulo:Editora Atlas. $7^{\mathrm{a}}$ edição.

McCutcheon, D. M., \& Meredith, J. R. (1993). Conducting case study research in operations 
management. Journal of Operations Management, 11(3), 239-256. http://dx.doi.org/10.1016/0272-6963(93)90002-7

Mentzer, J., Dewitt, W., Keebler, J., Min, S., Nix, N., Smith, C., \& Zacharia, Z. (2001). Defining supply chain management. Journal of Business Logistics, 22(2), 1-25. http://dx.doi.org/10.1002/j.2158-1592.2001.tb00001.x

Peck, H. (2005). Drivers of supply chain vulnerability: an integrated framework. International Journal of Physical Distribution \& Logistics Management, 35(4), 210-32. http://dx.doi.org/10.1108/09600030510599904

Pires, S. R. I. (2004). Gestão da Cadeia de Suprimentos: conceitos, estratégias, práticas e casos. São Paulo-SP, Editora Atlas.

Quinn, F. J. (1997). What's the buzz. Logistics Management, 36(2), 43-47.

Rainbird, M. (2004). Demand and supply chains: the value catalyst. International Journal of $\begin{array}{llll}\text { Physical Distribution \& Logistics Management, } & \text { 34(3/4). }\end{array}$ http://dx.doi.org/10.1108/09600030410533565

Rungtusanatham, M., Salvador, F., Forza, C., \& Choi, T. Y. (2003). Supply-chain linkages and operational performance: a resource-based view perspective. International Journal of Operations and Production Management, 23(9), 1084-1100. http://dx.doi.org/10.1108/01443570310491783

Silva, E. L., Menezes, E. M. (2000). Metodologia da pesquisa e elaboração de dissertação. Programa de Pós Graduação em Engenharia de Produção, Universidade Federal de Santa Catarina, Florianópolis, 118p.

Slack, N., \& Lewis, M. (2009). Estratégia de Operações. 2a ed. Porto Alegre: Bookman.

Stefanovic, D., Stefanovic, N., \& Redenkovic, B. (2009). Supply network modelling and simulation methodology. Simulation Modelling Practice and Theory, 17(4), 743-66. http://dx.doi.org/10.1016/j.simpat.2009.01.001

Tan, K. C., Lyman, S. B., \& Wisner, J. D. (2002). Supply Chain Management: a strategic perspective. International Journal of Operations \& Productions Management, 22(6), 614-631. http://dx.doi.org/10.1108/01443570210427659

Tang, C. S. (2006). Perspectives in supply chain risk management: a review. International Journal of Production Economics, 103(2), 451-8. http://dx.doi.org/10.1016/j.ijpe.2005.12.006

Towill, D. R., Childerhouse, P., \& Disney, S. M. (2002). Integrating the automotive supply chain: where are we now. International Journal of Physical Distribution and Logistics Management, 32(2), 79-95. http://dx.doi.org/10.1108/09600030210421705

Tummala, R., \& Schoenherr, T. (2011). Assessing and managing risk using the Supply Chain Risk Management Process (SCRMP). Supply Chain Management: An International Journal, 16(6), 474-83. http://dx.doi.org/10.1108/13598541111171165 


\section{Macrothink}

Journal of Management Research

ISSN 1941-899X 2015, Vol. 7, No. 5

Yin, R. K. (2004). Discovering the Future of the Case Study Method in Evaluation Research. Evaluation Practice, 15(3), 283-290. http://dx.doi.org/10.1016/0886-1633(94)90023-X

Wanke, P. F. (2010). Logística para MBA Executivo em 12 Lições. São Paulo. Atlas.

Williams, Z., Lueg, J. E., \& Lemay, S. A. (2008). Supply chain security: an overview and research agenda. The International Journal of Logistics Management, 19(2), 254-81. http://dx.doi.org/10.1108/09574090810895988

Wong, C. Y., Arlbjorn, F. S., \& Fohansen, F. (2005). Supply Chain Management Practices in Toy Supply Chains. Supply Chain Management: An International Journal, 10(5), 367-378. http://dx.doi.org/10.1108/13598540510624197

Wu, D., \& Olson, D. L. (2009). Introduction to the Special Section on Optimizing Risk Management Methods and Tools. Human and Ecological Risk Assessment, 15(2), 220-226. http://dx.doi.org/10.1080/10807030902760967

Zhao, X., Huo, B., Flynn, B., \& Yeung, J. (2008). The impact of power and relationship commitment on integration between manufacturers and customers in a supply chain. Journal of Operations Management, 26(3), 368-88. http://dx.doi.org/10.1016/j.jom.2007.08.002

\section{Copyright Disclaimer}

Copyright for this article is retained by the author(s), with first publication rights granted to the journal.

This is an open-access article distributed under the terms and conditions of the Creative Commons Attribution license (http://creativecommons.org/licenses/by/3.0/). 